\title{
AtTitudes of Young Population Towards MANAGING SOCIAL SUPERMARKETS IN Croatia
}

\author{
MARIC, I., KNEZEVIC, B. \& KovaC, J.
}

Abstract: Social supermarkets as a new phenomenon within social entrepreneurship are a non-profit form of organizations which prioritizes the fight against marginalization and social exclusion of some segments of the society. In Croatia, it is gaining popularity over the past five years, primarily due to the effects of the economic slowdown. The benefits of social supermarkets are heavily focused on the humanity, charity, social care and volunteerism of young population. This paper describes mechanisms and logics of operating activities of social supermarkets focusing on issues of participation of young population in everyday activities. In this paper, the results of the primary research on young population in Croatia are discussed. The primary survey included questions on (1) awareness of the existence of the social supermarkets and their role in society, (2) aims of operations and operational activities of social supermarkets, (3) attitudes towards volunteering in social supermarkets.

Key words: social supermarkets, non-profit organizations, social exclusion, management, organization
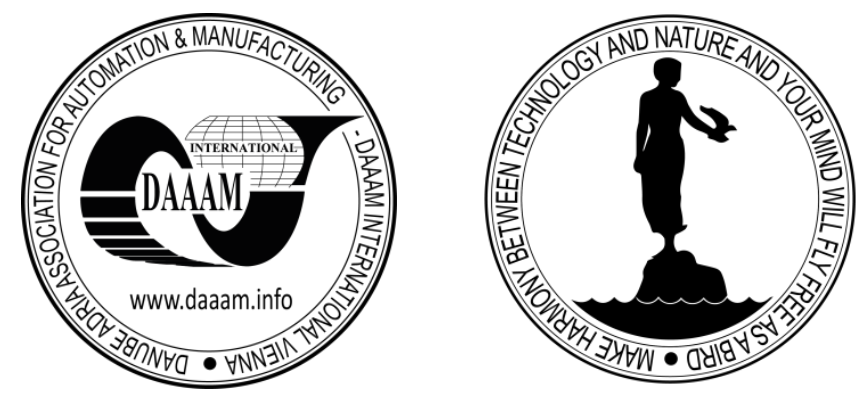

Authors' data: Dr. Sc. Maric, I[vana]*; Univ.Prof. Dr. Sc. Knezevic, B[lazenka]**, Kovac, J[elena] ${ }^{* * *}$ Faculty of Economics and Business, J. F. Kennedy 6, 10000, Zagreb, Croatia,imaric@efzg.hr, bknezevic@efzg.hr, jkovac1@efzg.hr

This Publication has to be referred as: Maric, I[vana]; Knezevic, B[lazenka] \& Kovac, J[elena] (2015). Attitudes of Young Population Towards Managing Social Supermarkets in Croatia, Chapter 06 in DAAAM International Scientific Book 2015, pp.059-066, B. Katalinic (Ed.), Published by DAAAM International, ISBN 978-3902734-05-1, ISSN 1726-9687, Vienna, Austria

DOI: $10.2507 /$ daaam.scibook.2015.06 
Maric, I.; Knezevic, B. \& Kovac, J.: Attitudes of Young Population Towards Mana...

\section{Introduction}

Environment characterized by crisis, rising unemployment and poverty is an emergency call out and also the breeding ground for the development of new economic solutions. By definition, social entrepreneurship is the creation of socio-economic structures, relationships, institutions, organizations and measures that result in sustainable social benefits and further development (Skrtic, 2006, pp. 20-26).

As the name „social supermarket" suggests, it is primary an initiative of citizens through nongovernmental organizations that fosters a social inclusion, which involves the creation of social change and an applied aspect of distributive trade activity through the free provision of certain goods (mostly concerning the necessary groceries) to socially vulnerable individuals (Maric, 2013). Citizens participation in social supermarkets is noticeable through social entrepreneurial action and creation of new social values, trying to correct the imbalances created in the market and social subsystems (Maric, 2013).

Considering these terms it can be concluded that the backbone of their relationship is the concept of the social responsibility. Both, social supermarkets and social entrepreneurship are a part of a new, modern approach to humanitarian and charitable activities. Because of their versatility, non-profit organizations can be observed and defined in various ways. On one hand, they can be perceived as organizations with operations focused on non-profit and philanthropic activities within the organization. On the other hand, they can be considered as organizations that promote and encourage solidarity as a non-economic variable that reflects its mission. Placed in such framework, nonprofits are described as organizations that do not generate profits, or, if it's created, they do not invest it in a capital increase, but in various charitable activities, organizations and associations with dominantly humanitarian goals (Paunovic, 2015). Thus, their ultimate aim is to create positive social values of the organization. According to the Register of non-profit organizations (Register of nonprofit organizations, web), which is kept by the Ministry of Finance, in Croatia, up to June 2014, there were 26,362 registered non-profit organizations; which is a considerable number for such a small country as Croatia.

One type, of non-profit organizations is social supermarkets. The social supermarket can be defined as the meeting place for supply of products or services, which do not contain price character, and demand for those same products or services, and that is not based on financial possibilities and abilities of providing for the said goods. Social supermarkets, as a recent social innovation within the field of social enterprises, become an important place of exchange that promotes social values of solidarity, networking and philanthropy, and creates significant social impact (Puljiz et al, 2005, p. 405). Holweg and Lienbacher (2011) define social supermarket as a supermarket food retailer that sells food to limited groups of people who live at the risk of poverty. Furthermore, social supermarkets represent a specific form of social enterprises that include both social and market business components (Maric and Knezevic, 2014).

In this paper we will address the problem of social exclusion and the role of social supermarkets in its overcoming, then we will address the basic issues of management in social supermarkets and, finally, we will discuss the results of the primary research 
on attitudes of younger population towards operation of social supermarkets and volunteering in social supermarkets

\section{Social supermarkets as a solution for social exclusion}

Social exclusion is one of the negative consequences of poverty and the term "socially excluded citizens" includes those members of society who, due to the deprive material status caused by factors beyond their control, cannot participate in the normal activities as citizens of the certain society (Sucur, 2004). While the term poverty is focused on a material deprivation and mainly is focused on a lack of financial resources, the term of social exclusion is multidimensional and includes deprivation in employment, education, social contacts and other aspects of life (Sucur, 2006). Therefore, the aim of the fight against poverty is redistribution of financial resources, while the aim of the fight against social exclusion involves a variety of political and social measures (Sucur, 2006).

When the competent national authorities fail to solve the existential problems of socially excluded citizens, than voluntary (civil) sector is filling in the gap through the work of the charity apparatus, trying to remedy this problem as much as possible and to reduce the harmful effects of poverty. One kind of social activities and social organization within charity apparatus is social supermarket. Therefore the social supermarket is a type of social entrepreneurship that focuses on volunteering and achieves social impact through the reduction of poverty and fostering solidarity, social responsibility and civic engagement in addressing the issue of social exclusion (Maric and Knezevic, 2014).

In Croatia, the first social supermarket as a successful social entrepreneurship initiative was opened in Rijeka in April 2011 by the nonprofit organization "Youth Against Hunger" in cooperation with the city government (Social Supermarket in Rijeka, web). The main purpose of this initiative was to help socially endangered citizens, not only once a year, but all year long by offering them the possibility to choose food and other necessary things for household for free.

\section{Basic management issues in social supermarkets}

Management is defined as the process by which a manager of an organization efficiently utilizes resources to achieve goals together with others and through others in the most efficient way (Lorenzana, 1998, p. 4). But, also, management as a term can refer to group of people who are responsible for directing the workforce in a manner oriented towards meeting goals or objectives of organization (Lorenzana, 1998, p. 4).

The main guiding principle of social supermarket management is accompanied by a non-profit character that complements the entire social sector and this principle is shifting the planning, control and performance towards other values, not money and profits (Alfirevic et al, 2013, p. 181). And those values are very hard to measure in 
terms of quantitative approach. Nonetheless material things (goods and financial resources) are necessary for everyday operation of social supermarkets, values that are of strategic importance includes: satisfaction of users, help to others, preserved dignity, happiness derived from serving others and so on.

Within the managerial aspect of social supermarkets, we distinguish various groups of stakeholders that are directly involved in every-day activities, namely: (1), volunteers of social supermarket, (2) sponsors (donors), (3) end-users, and (4) management and/or paid employees responsible for the operation activities and government of social supermarket. In advance, the focus will be on younger population as a source of volunteers at social supermarkets, while other stakeholders are not addressed in this paper.

\section{Results of the primary research on the perceptions of young people about social supermarkets}

A primary survey was conducted in order to determine the level of awareness among young population about the concept of social supermarket. Given the fact that this area has no significant scientific background, in this paper will be explored how young people perceive the very concept of social supermarkets and their role in social and economic change at a certain country. Furthermore, one of the goals of the primary research was to determine the state of awareness of young people about the socioeconomic situation in Croatia regarding the pressing problem of poverty.

Through questions about the level of volunteering in Croatia and involvement in various volunteering programs, together with the involvement of young people in voluntary activities, and their attitude towards volunteering in social supermarkets were explored. The study was conducted on a sample of 150 students of the University of Zagreb. Considering the increasing tendency of young people using social networks and the Internet, it the survey was carried out electronically.

In order to determine extent of familiarity with the notion of "social supermarkets", respondents were asked how they identify the term. Observing results are displayed in Figure 1. It is obvious waste number of examinees (82\%) is familiar with the very notion of the term "social supermarket". Furthermore, a significant number of examinees (44\%) are quite familiar and/or completely understand the term "social supermarket". A certain number of them are partly familiar (34\%), and a small number only have heard for the term (4\%). But there is a part of surveyed population $(18 \%)$ to which the notion of "social supermarket" is completely unknown.

When asked to give a definition of social supermarkets, examinees gave several types of answers. Primarily they defined social supermarkets as a form of social entrepreneurship (34\%), then as non-profit organizations (29.3\%). Following is an opinion that social supermarkets are so-called "charity shops" (23.3\%); while only a small number of surveyed population (12\%), identifies social supermarkets as a specific form of retail. 

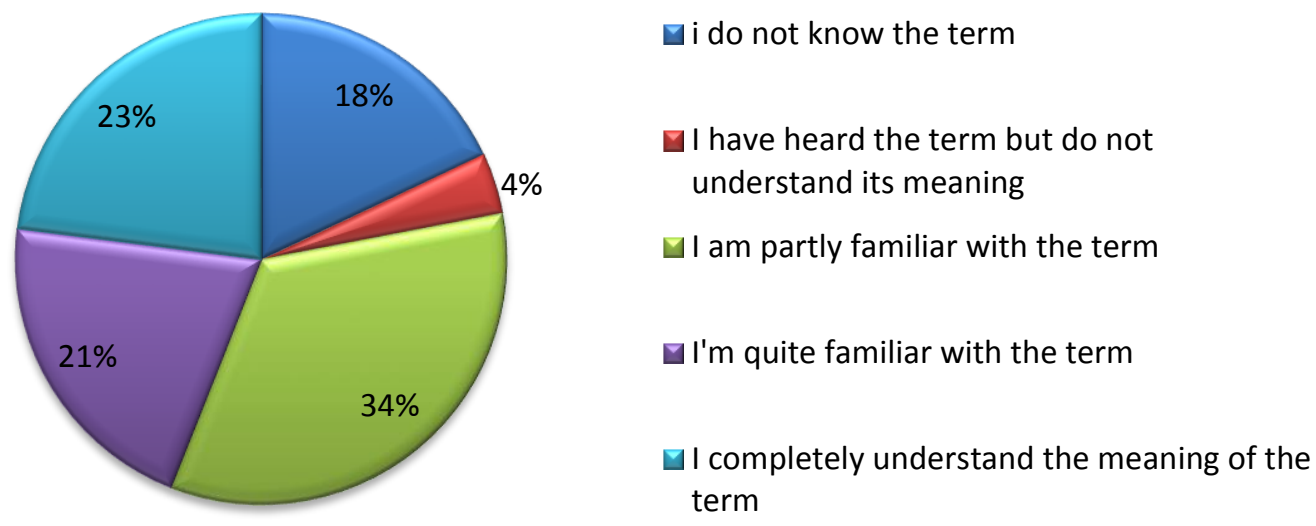

$\square$ i do not know the term

I have heard the term but do not understand its meaning

$\square \mathrm{I}$ am partly familiar with the term

I'm quite familiar with the term

$\square$ I completely understand the meaning of the term

Fig. 1. The level of awareness of students to the concept of "social supermarkets" Source: own research

Data in Figure 2 shows that the majority of examinees (69\%) believe that social supermarkets only partially solve the problem of vulnerable members of society in Croatia. Further, only a smaller portion of surveyed students (18\%) sees social supermarkets as a negative phenomenon, which not only does not solve the problem of vulnerable members of society, but also promotes social exclusion, inactivity of people in job-searching activities and encourage them to exploit the social situation. Almost negligible part of the surveyed students (1\%), think of social supermarkets as of complete solution to the problem of poverty in Croatia.

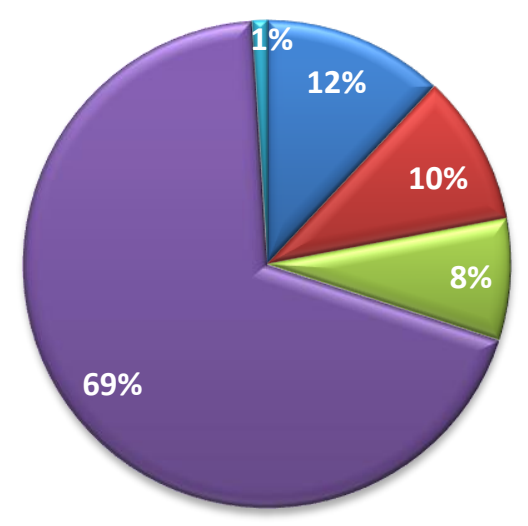

$$
\begin{aligned}
& \text { I don't know } \\
& \text { do not resolve the problem and encourage } \\
& \text { social exclusion } \\
& \text { do not solve the problem but encourages } \\
& \text { idleness and exploitation of the situation } \\
& \square \text { partially solve the problem }
\end{aligned}
$$

$\square$ completely solve the problem

Fig. 2. The level of awareness of students to the concept of "social supermarkets" Source: own research

Reasons for the existence of social supermarkets are numerous and it is difficult to determine the order of the urgency of problems they are connected to. Therefore, it is also complex to determine the key reasons for their existence. Table 1 presents the list of key reasons for the existence of social supermarkets, according to attitudes of surveyed young population and they are ranked from the most important to the least important. 
Maric, I.; Knezevic, B. \& Kovac, J.: Attitudes of Young Population Towards Mana...

In students' opinion, there are three main problems that social supermarkets solve. Those are: fight against poverty, solving food waste and preservation of people's dignity.

The 3 key reasons for the existence of social supermarkets

1. fight against poverty

2. the problem of food wastage

3. preservation of human dignity

Tab. 1. Perception of the surveyed students about the key reasons for the existence of social supermarket

Source: own research

Considering that the social supermarkets are nonprofit organizations, the question of responsibility for their functioning raises, as well as the question of management competences in social supermarkets. According to the survey, responsibility for the functioning of the social supermarket is ranked as shown in Table 2. Thus, younger population, as the stakeholder who is primarily responsible for the functioning of the social supermarket, recognized the government. Following are local and religious communities, relevant ministries and civil associations, and eventually private enterprises and other organizations.

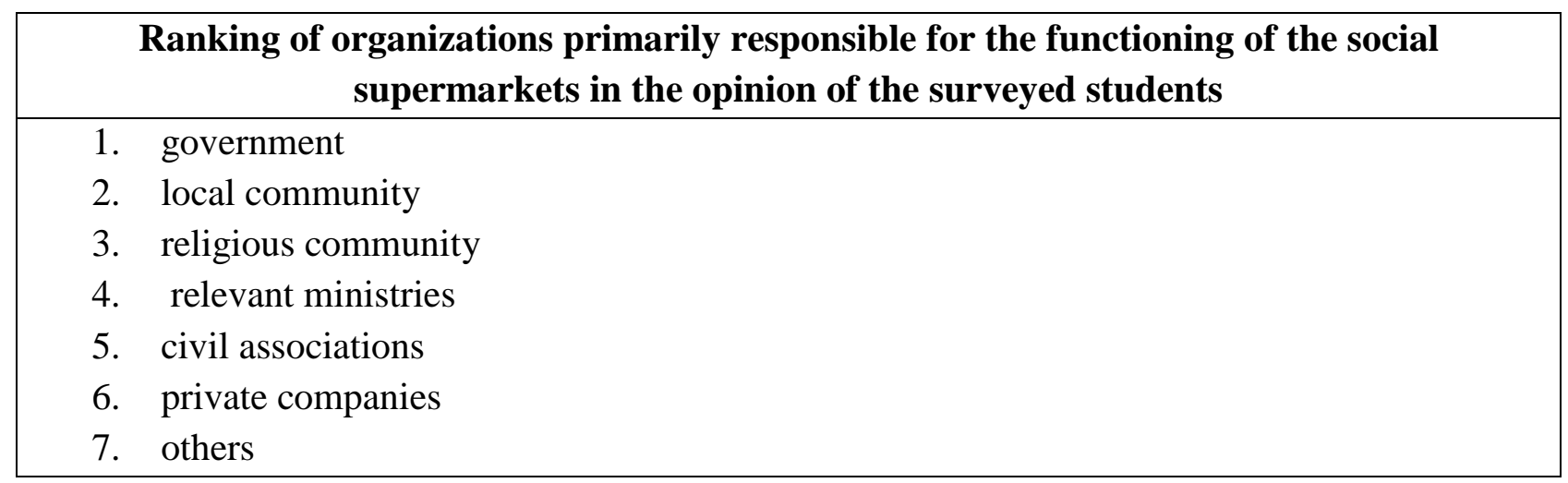

Tab. 2. Perception of the surveyed students about the competence of the management of social supermarkets

Source: own research

Turning to the workforce of the social supermarkets, it is mainly made up of volunteers. Volunteers with their work and unpaid involvement in activities of a nonprofit organization, contribute to its activities and everyday operations. Therefore, within the primary research, the involvement and interest in volunteering among students was investigated.

Figure 3 clearly shows that the majority of the respondents has, so far, no experience of volunteering in social supermarkets (98\%), of which a few are not even interested to gain such experience (5\%), while almost one-third of respondents $(29 \%)$ would like to volunteer in social supermarkets. 


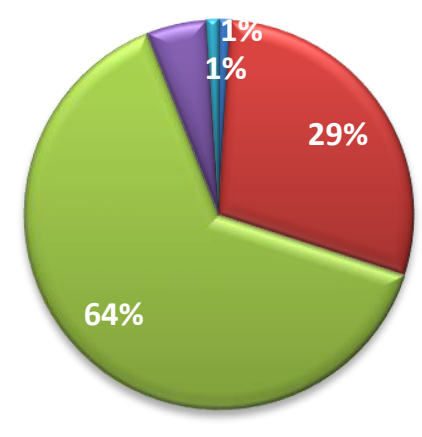

$\square$ yes, I am currently a volunteer

ano, but I would like to volunteer

$\square$ no

$\square$ no and I don't want to volunteer

$\square$ no response

Fig. 3. The level of awareness of students to the concept of "social supermarkets" Source: own research

\section{Conclusions}

Social supermarkets found their very purpose in the struggle against poverty through the active work of volunteers, organization of different actions to gain financial supporters and donors, organization of everyday operation activities regarding distribution of necessary goods in order to preserve a human dignity of socially excluded citizens. As an economic crisis in various EU countries is taking a place, social supermarkets are becoming a significant part of the distribution channels. Due to its domain of action, they represent a form of social innovation as an addition to traditional distribution channels. They are, also, an entrepreneurial venture because of the way they engage different factors for the purpose of achieving objectives.

In this paper we discussed the awareness of young population on very existence of the social supermarket as a form of social entrepreneurship, we analyzed the attitudes towards volunteering in social supermarkets and we addressed the issue of responsibility for social supermarkets' operation. According to the findings, young population is familiar with the existence of the social supermarkets, but one third have a questionable attitude towards their contribution to the society (see Figure 2). A waste number of young people are not volunteering, yet. And they perceive the government and local communities as the most responsible actors for supporting social supermarkets. For further studies it would be interesting to consider several problems of management operating for social supermarkets, the issue of the measurement of social influence and results applying the model 3E (see Pastuszkova, E. and Palka, 2011) or the possibilities of using the Six Sigma model for improving the performance of these organizations as it is suggested by Kralikova et al (2011).

\section{Acknowledgement}

This work has been fully supported by Croatian Science Foundation under the project UIP2014-09-4057 "Potentials and obstacles of Social Supermarkets Development in Central and Eastern Europe".

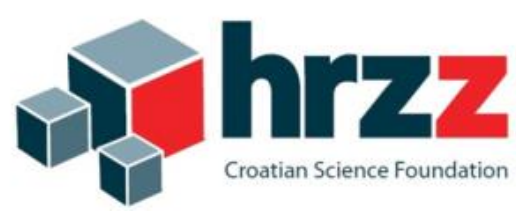


Maric, I.; Knezevic, B. \& Kovac, J.: Attitudes of Young Population Towards Mana...

\section{References}

Alfirevic, N., Pavicic, J., Najev Cacija,Lj., Mihanovic, Z., Matkovic, J. (2013): Basics of non-profit organization marketing and management, (in Croatian: Osnove marketinga i menadžmenta neprofitnih organizacija), Skolska knjiga, Zagreb, ISBN 978-953-0-30278-5

Holweg, C., Lienbacher, E. (2011): Social supermarkets - a New Challenge in Supply Chain Management and Sustainability, Supply Chain Forum, 11(4), pp. 50-58, ISSN: $1625-8312$

Kralikova, R., Wessely, E. \& Rusko, M. (2011): The use of Six Sigma method within the framework of environmental management at Katalinic, B., ed., Annals of DAAAM for 2011 \& Proceedings of the 22nd International DAAAM Symposium, ISSN: 17269679, ISBN: 978-3-901509-83-4, pp.187-188

Lorenzana, C. C. (1998): Management Theory and Practice, Rex Books, St. Quenzon City, ISBN: 971-23-1328-X

Maric, I. (2013): Social Supermarkets as a Social Innovation, at Knego, N., Renko, S., Knežević, B., eds. (2013), Trade Perspectives 2013: Supply Chain Relationships, University of Zagreb: Faculty of Economics Zagreb, pp.296-305, ISBN: 978-9536025-81-7

Paunovic, Z . (2015): Non-profit organizations - a contribution to the clarification of concepts, available at http://www.fpn.bg.ac.rs/wp-content/uploads/\%C5\%BDarkoPaunovi\%C4\%87-Neprofitne-organizacije-\%E2\%80\%93-prilog-pojmovnomrazja\%C5\%A1njenju.pdf, accessed on 25th May 2015

Maric, I., Knezevic, B. (2014): Social Supermarkets as a New Retail Format Inspired by Social Needs and Philanthropy - The Case of Croatia, Global Business \& Economics Anthology, 2(12) 2014, pp.278-286, ISSN: 1553-1392

Pastuszkova, E. \& Palka, P. (2011): Performance management in the sphere of public administration at Katalinic, B., ed., Annals of DAAAM for 2011 \& Proceedings of the 22nd International DAAAM Symposium, ISSN: 1726-9679, ISBN: 978-3-901509-834, pp.1487-1488

Puljiz, V., Bezovan, G., Sucur, Z., Zrinscak, S. (2005): Social policy: history, systems, glossary, (in Croatian: Socijalna politika: povijest, sustavi, pojmovnik), University of Zagreb: Faculty of Law, ISBN: 9536714752.

Register of non-profit organization, Croatian Ministry of Finance, available at: https://banovac.mfin.hr/rnoprt/, accessed on 23rd May 2015

Skrtic, M. (2006): Entrepreneurship, (in Croatian: Poduzetništvo), Sinergija,

Zagreb, ISBN: 953-6895-33-1

Social supermarket in Rijeka by University of Rijeka: Cultural Studies, available at: http://www.ffri.hr/cultstud/index.php/k2-extra-fields/kultura-u-akciji/akcija-idrustvo/164-socijalna-samoposluga, accessed on 17th May 2015

Sucur, Z. (2004): Socijalna isključenost: pojam, pristupi i operacionalizacija, Revija za sociologiju (Social exclusion: concept, approach and operationalization, Sociological), 35 (1-2), pp. 45 - 60, ISSN 0350-154X

Sucur, Z. (2006): Siromaštvo, višedimenzionalna deprivacija i socijalna isključenost u Hrvatskoj, Revija za sociologiju, (Poverty, Multidimensional Deprivation and Social Exclusion in Croatia, Croatian Sociological Review) 37 (3-4), pp.131-147, ISSN 0350-154X 